\title{
HIV/AIDS related knowledge and attitude among female sex workers in Tehran/Iran
}

\author{
Saeid Madani Ghahfarokhi" ${ }^{*}$, Ameneh Setareh Forouzan ${ }^{1}$, Payam Roshanfekr ${ }^{1}$, Mohamad Ali Mohammadi ${ }^{1}$, \\ Masoumeh Dejman ${ }^{1}$, Meroeh Vameghi ${ }^{1}$, Mirtaher Mousavi ${ }^{1}$, Hassan Rafiee ${ }^{1}$, Mansoureh Hemmasian Ettefagh ${ }^{1}$, \\ Malihe Sheyani ${ }^{2}$
}

From $16^{\text {th }}$ International Symposium on HIV and Emerging Infectious Diseases Marseille, France. 24-26 March 2010

\section{Background}

To assess the knowledge and attitude of female sex workers regarding HIV/AIDS and utilization of health services prepared for them in Tehran capital city of Iran.

\section{Methods}

This study includes two phases. Phase one: A cross-sectional survey was conducted among 280 female sex workers in various urban areas in Tehran. During the survey a 114 item researcher designed questionnaire was used. The validity and reliability of questionnaire was assessed during a pilot study. Phase two: Following the quantitative survey a qualitative study was done which 39 in-depth interviews were conducted to gain insights into the context of their risky sexual behaviors and suggestions for feasible HIV primary prevention interventions.

\section{Results}

The mean age of the respondents was 27.6 years and majority of them were literate. Among study population $43.1 \%$ were born in another province besides Tehran. The mean years of sex work was reported as 5.8 years by participants in this study. About $97.5 \%$ of them reported that they have heard about HIV/AIDS and 98.5\% reported that they have heard about condom. Among respondents 70\% believed that there is no feasibility for confidential HIV test in Tehran. The findings revealed that $30.3 \%$ of participants in this study were forced to take an HIV/AIDS infectious test exam against their personal will.

* Correspondence: saeid_madani@yahoo.com

${ }^{1}$ Social Welfare and Rehabilitation Sciences University, Tehran, Iran, Islamic Republic of

\section{Discussion}

Although majority of female sex workers in Tehran were familiar with HIV/AIDS and condom but their knowledge was superficial. Most of study group had serious concerns about referring to health clinics for HIV/AIDS tests and they had negative attitudes in this regard. It seems that peer group education, providing secure stations for HIV/AIDS testing and providing easy access to condom would be useful to address this problem.

\section{Author details}

'Social Welfare and Rehabilitation Sciences University, Tehran, Iran, Islamic Republic of. ${ }^{2}$ social sciences department, Tehran, Iran, Islamic Republic of.

Published: 11 May 2010

doi:10.1186/1742-4690-7-S1-P130

Cite this article as: Ghahfarokhi et al.: HIV/AIDS related knowledge and attitude among female sex workers in Tehran/Iran. Retrovirology 2010 7(Suppl 1):P130.

Submit your next manuscript to BioMed Central and take full advantage of:

- Convenient online submission

- Thorough peer review

- No space constraints or color figure charges

- Immediate publication on acceptance

- Inclusion in PubMled, CAS, Scopus and Google Scholar

- Research which is freely available for redistribution

Submit your manuscript at www.biomedcentral.com/submit
C Biomed Central 